\title{
高温での銅材の衝撃疲労強度とその疲労過程にお梳る サイクリッククリープ塑性変形挙動
}

岡部永年* 矢野利 行** 柏 谷 英 夫***

\author{
Impact Fatigue Strength and Behavior of Plastic Deformation due \\ to Cyclic Creep for Copper under Repeated Impact \\ Tensile Loads at High Temperatures \\ by

\section{Nagatoshi Okabe*, Toshiyuki Yano** and Hideo Kashiwaya***}

The impact fatigue tests for oxygen-free copper and high strength copper were carried out at various temperatures between 100 and $250^{\circ} \mathrm{C}$ as well as at room temperature. The fatigue strength and plastic deformation due to cyclic creep under impact tensile loads were analyzed in consideration of temperature-dependence and static tensile properties.

The impact fatigue strength was found to be expressed by the formula of $\sigma\left(N_{f} T\right)^{m} 0=D_{0}$, where $m_{0}$ and $D_{0}$ are the material constants for impact fatigue strength at each high temperature $T_{\theta}(\mathrm{K})$. The values of $m_{0}$ and $D_{0}$ depended on the temperature and were expressed by the formulas of $m_{0}=$ $m_{0} *+m_{1} *\left(T_{\theta}-273\right)$ and $D_{0}=D_{0} * \exp \left(Q / k T_{\theta}\right)$.

The behavior of cyclic creep plastic deformation was expressed by a formula including only plastic strain $\varepsilon_{p}$ and normalized number of cycles $N / N_{f}$, which is independent of impact stress $\sigma$, duration time $T$ and temperature $T_{\theta}$. The values of $m_{0}, D_{0}$ and main material constants $\left(a_{1}, a_{2}\right)$, which appear in the formula expressing the cyclic deformation, had distinct relationships with the ultimate strength $\sigma_{B}$, reduction of area $\phi$ and elongation $\delta$ in static tension. Impact fatigue strength and cyclic creep plastic deformation at high temperatures can be well estimated through these relationships from the static tensile properties at room temperature.

キー・ワード : 高温衝撃疲労強度, 温度依存性, サイクリッククリープ, 軟質無酸素銅, 高力銅

\section{1 緒言}

純銅や高力鋼はガス絶縁開閉装置や真空開閉装置な ぞの重電開閉機器に拈ける電極軸や電極構造部材など に使用され，開閉動作時に衝撃荷重を繰返し受ける. それゆえ，著者らはタフピッチ銅，無酸素銅，高力銅 などの各種銅材に対して常温での衝撃引張疲労強度お よびその疲労過程でのサイクリッククリープ塑性変形 挙動について究明し, 前報で報告した. 一方, これら の電極軸や電極構造部材は接続部の経時変化による接 触抵抗の增大あるいは開極時のアーク熱などが起因す る温度上昇も考慮して抢く必要がある。したがって, 衝撃疲労強度やその疲労過程でのサイクリッククリー プ塑性変形挙動の温度依存性についても究明しておく ことが，これらの機械強度設計上，極めて重要である. ところが, 通常の動的荷重に対する低サイクル疲労特 性については Manson-Coffin の式 $\Delta \varepsilon_{p} N_{f}{ }^{\alpha}=C$ が高
温においても適用できるといら研究あるいは高温低サ イクル疲労に和ける負荷（ひずみ）の繰返し速度効果 に関する研究が過去に数多く行われてはいるが，高温 条件下での繰返乙衝撃荷重に対する疲労強度特性やサ イクリッククリープ塑性変形特性についての研究はほ とんど見あたらない。

そこで，本研究では軟質無酸素銅と高力銅に対して 高温での衝撃引張疲労試験を行い銅材の高温衝撃疲労 強度特性祘よびその疲労過程でのサイクリッククリー プ塑性変形特性について明らかにした。 ついでこれら の特性に和ける諸パラメータと静的引張特性值との関 連性打よび衝撃疲労強度特性パラメータの温度依存性 について解析を行った．これらの結果より高温条件下 での繰返乙衝撃荷重に対する疲労強度や破壞寿命拉上 びその疲労過程での塑性形挙動を静的引張特性值に基 づき推定・評価できることを明らかにした.

$\dagger \quad$ 原稿受理 昭和61年10月8日 Received Oct. 8, 1986

* 正会 員 (株)東芝重電技術研究所 横浜市鶴見区未広町, Heavy Apparatus Engineering Laboratory, Toshiba Corporation, Suehirocho, Tsurumi-ku, Yokohama

** 正会 員 (株)東芝重電技術研究所 府中市東芝町, Heavy Apparatus Engineering Laboratory, Toshiba Corporation, Toshiba-cho, Fuchu

*** (株)東芝重電技術研究所 横浜市鶴見区末広町, Heavy Apparatus Engineering Laboratory, Toshiba Corporation, Suehiro-cho, Tsurumi-ku, Yokohama 


\section{$2 \cdot 1$ 供試材および試験片}

験

本実験に供した銅材は市販の無酸素銅 $(99.98 \% \mathrm{Cu})$ おうよび高力銅 (0.75\% Cr-0.18\% Zr-0.01\% $\mathrm{Si}$ 銅合金) である. 試験片としては Fig. 1 に示す寸法形状に機 械加工したのち真空焼なまし $\left(800^{\circ} \mathrm{C} \times 1\right.$ 時間) を行 った. 機械的性質を Table I に示す.

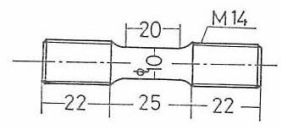

Fig. 1. Shape and dimensions of a specimen.

Table I. Mechanical properties.

\begin{tabular}{|c|c|c|c|c|}
\hline & $\begin{array}{l}0.2 \% \text { proof } \\
\text { stress } \\
\sigma_{0.2} \\
\left(\mathrm{kgf} / \mathrm{mm}^{2}\right)\end{array}$ & $\begin{array}{c}\text { Tensile } \\
\text { strength } \\
\sigma_{B} \\
\left(\mathrm{kgf} / \mathrm{mm}^{2}\right)\end{array}$ & $\begin{array}{l}\text { Elongation } \\
\delta(\%)\end{array}$ & $\begin{array}{c}\text { Reduction } \\
\text { of area } \\
\varphi(\%)\end{array}$ \\
\hline $\begin{array}{l}\text { Oxygen-free } \\
\text { coppers }\end{array}$ & 21.6 & 2.2 & 69.4 & 86.7 \\
\hline $\begin{array}{l}\text { High-strength } \\
\text { coppers }\end{array}$ & 29.9 & 5.9 & 49.1 & 71.3 \\
\hline
\end{tabular}

\section{$2 \cdot 2$ 実験方法}

高温衝撃疲労試験には円筒と丸棒との縦衝撃現象を 利用した繰返乙衝撃引張荷重装置に低周波加熱炉を取 り付けたものを用いた. Fig. 2 は試験片の取り付子方 おさよび加熱部構成の概念図を示す。実験方法としては 100，150，200，250 C の各温度条件にて衝撃引張荷重 を試験片が破断するまで繰返した。. 各 1 回の衝撃引張

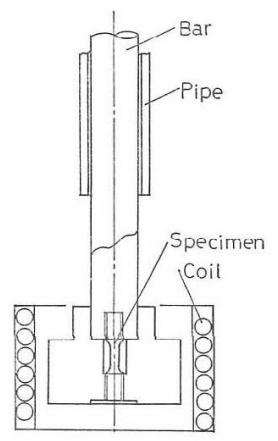

Fig. 2. Figure showing how to set up and heat a specimen in the experimental apparatus used.

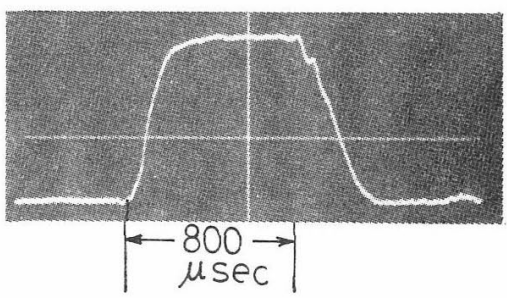

Fig. 3. An example of measured impact stress wave.
荷重によって試験片に生じる衝撃応力波形は，Fig. 3 に示すよらなほぼ台形波状の単一パルスである。それ ゆ光, 試験片が破壊するきでの衝撃荷重の繰返し数を 衝撃疲労破壞寿命 $N_{f}$ とした。一方, 試験片に生じる 衝撃引張応力のの大きさおよびその負荷持続時間 $T$ は

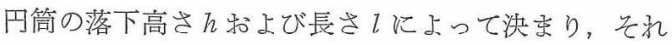
ぞれ次式で表される。

$$
\begin{gathered}
\sigma=\frac{A_{1} A_{4}}{A_{2}\left(A_{1}+A_{4}\right)} \sqrt{E_{\gamma}} / \overline{2 h} \\
T=2 l / C
\end{gathered}
$$

ここで, $A_{1}, A_{2}, A_{4}$ は吊り丸棒, 試験片, 円筒の 各横断面積, $E, \Upsilon, C$ は棒, 円筒材の鋼のヤング 率, 比重量执よび鋼中の弾性波伝ぱ速度である。

衝撃疲労試験に括ける負荷持続時間 $T$ の条件として は $l=2000 \mathrm{~mm}$ の円筒を用いた $T=800 \mu \mathrm{sec}$ の実験 を重点的に行い， $l=1000,3000 \mathrm{~mm}$ の円筒を用いた $T=400,1200 \mu \mathrm{sec}$ の実験は $T$ の影響を確認するため の実験として行った。衝撃疲労過程でのサイクリック クリープ塑性変形は各衝撃負荷後の試験片平行部の長 さ $l_{N}$ を実測し，次式のように塑性ひずみ $\varepsilon_{p}$ として 求めた。

$$
\varepsilon_{p}=\left(l_{N}-l_{0}\right) / l_{0}
$$

ここで, $l_{0}, l_{N}$ は試験片平行部の初期おるび $N$ 回目 の衝撃負荷後の長さである.

\section{3 実験結果および考察}

\section{$3 \cdot 1$ 高温での衝撃疲労強度特性}

Fig. 4 (a) は軟質無酸素銅和よび高力銅がそれぞれ $100 ， 150 ， 200,250^{\circ} \mathrm{C}$ の各温度条件下で $T=800 \mu \mathrm{sec}$ の衝擊引張応力を繰返し受けた場合の衝撃疲労強度 を破壞寿命 $N_{f}$ との関係で両対数方眼紙上に示してい

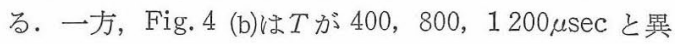
なる衝撃引張応力を繰返乙受けた場合の衝撃疲労強度 $\sigma$ を, $N_{f}$ までの累積負荷時間 $N_{f} T$ との関係で両対 数方眼紙上に示している。これより高温での衝撃疲学 強度も常温での場合同様次式で表されることがわかる。

$$
\sigma\left(N_{f} T\right)^{m_{0}}=D_{0}
$$

ここで， $m_{0}, D_{0}$ は各温度条件下での材料定数でめ り， $m_{0}$ は強度劣化指数， $D_{0}$ は強度定数そ气れぞれ表 す衝撃疲労強度特性パラメータである。

Fig. 5 (a)(b)は両銅材の衝撃疲労强度特性パラメータ $m_{0}, D_{0}$ の温度依存性を元したすのである. Fig. 5 (a) の方は $m_{0}$ と絶詨温度 $T_{\theta}(\mathrm{K})$ との関係を示し, 高温 になるほど $m_{0}$ は直線的に大きくなる傾向が告り，次 式で表される。

$$
m_{0}=m_{0} *+m_{1}^{*}\left(T_{\theta}-273\right)
$$

ここで, $m_{0} *$ は温度 $0^{\circ} \mathrm{C}$ での強度劣化指数, $m_{1} *$ は $1^{\circ} \mathrm{C}$ 温度上昇あたりの $m_{0}$ の增分を表す. Table II に 各銅材の $m_{0} *, m_{1} *$ の值を示す。 

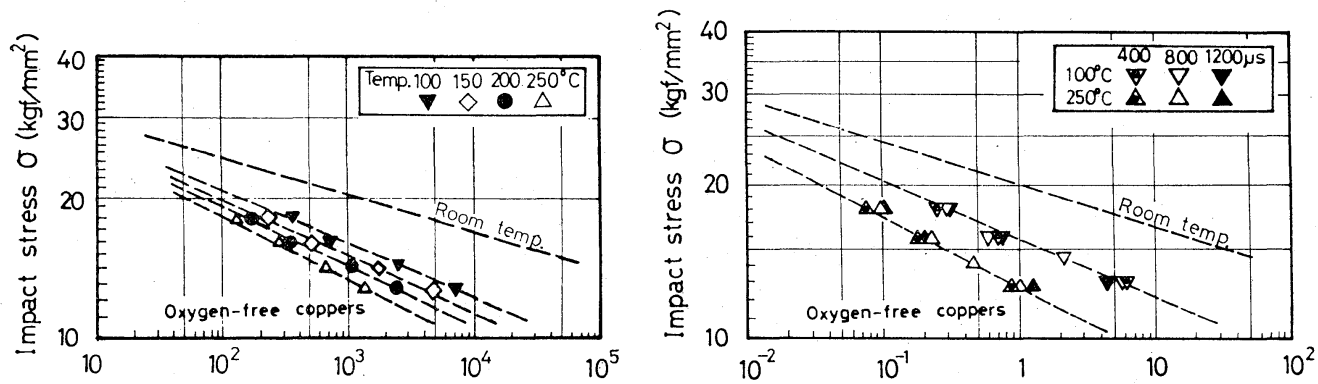

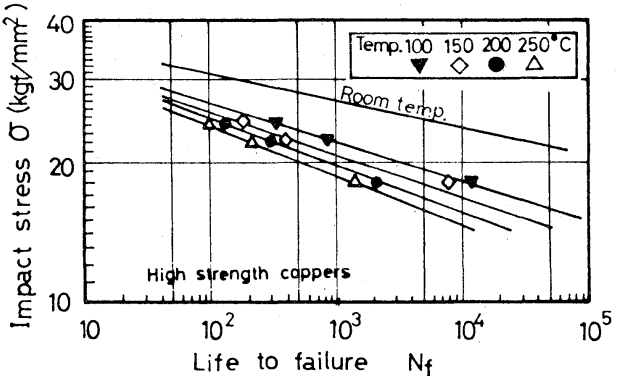

(a)

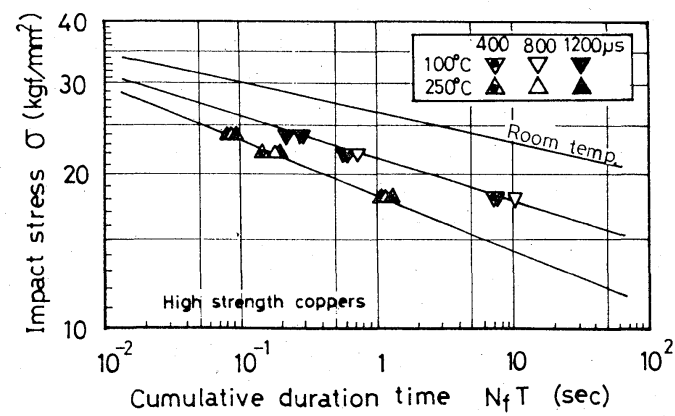

(b)

Fig. 4. Relation between impact fatigue strength $\sigma$ and life to failure $N_{f}$ (a), relation between $\sigma$ and cumulative duration time $\left(N_{f} T\right)$ (b) for two kinds of copper subjected to repeated impact tensile loads under room and high temperatures.
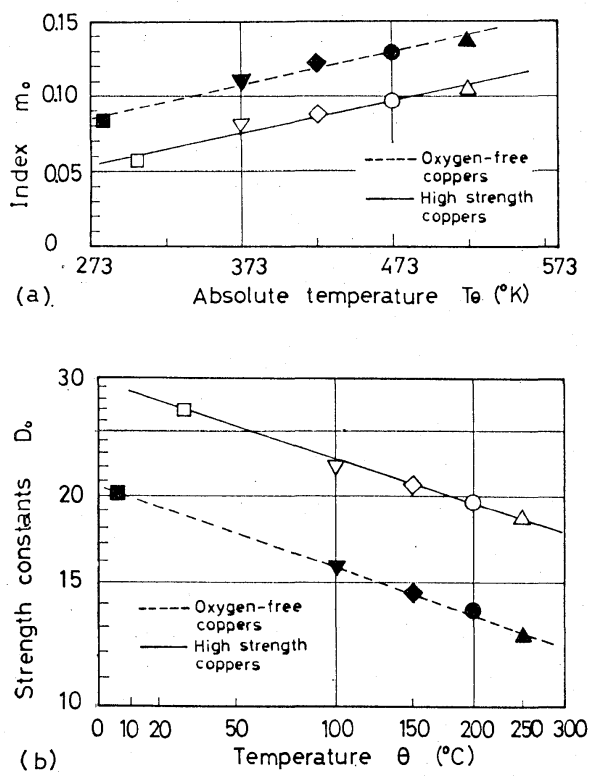

Fig. 5. Relation between the material constants $m_{0}, D_{0}$ and temperature.

一方, Fig. 5 (b)の方は, 強度定数 $D_{0}$ と温度 $\theta^{\circ} \mathrm{C}$ $\left(-1 / T_{\theta}\right)$ との関係を示したものである。高温になる ほど， $D_{0}$ は低下寸る傾向があり，次式で表される.

$$
D_{0}=D_{0} * \exp \left(Q * / T_{\theta}\right)=D_{0} *\left(Q / k T_{\theta}\right)
$$

ここで, $D_{0} *, Q^{*}$ は材料定数であり，Qは $Q^{*}$ の值 をボルツマン係数 $k$ で除し，活性化エネルギの単位で
Table II. Material constants $m_{0}^{*}, m_{1} *$ in the formula with relationship between $m_{0}$ and $T_{\theta}$.

\begin{tabular}{c|c|c}
\hline & $m_{0} *$ & $m_{1}{ }^{*}$ \\
\hline Oxygen-free coppers & 0.08537 & $2.225 \times 10^{-4}$ \\
High-strength coppers & 0.05365 & $2.215 \times 10^{-4}$ \\
\hline
\end{tabular}

Table III. Material constants $D_{0} *, Q^{*}, Q$ in the formula with relationship between $D_{0}$ and $T_{\theta}$

\begin{tabular}{l|c|c|c}
\hline \hline & $\begin{array}{c}D_{0}^{*} \\
\left(\mathrm{kgf} / \mathrm{mm}^{2}\right)\end{array}$ & $\begin{array}{c}Q^{*} \\
(\mathrm{eV})\end{array}$ & $\begin{array}{c}Q \\
\left(\mathrm{eVK}^{-1}\right)\end{array}$ \\
\hline Oxygen-free coppers & 7.539 & 274.0 & 0.02361 \\
High-strength coppers & 11.09 & 263.3 & 0.02269 \\
\hline
\end{tabular}

表した值であり，各銅材の塑性変形のための活性化エ ネルギに相当する. Table III に各銅材の場合の $D_{0} *$, $Q^{*}, Q$ の值を示す.

以上のように, 両銅材において, 衝撃疲労強度特性 パラメータ $m_{0}, D_{0}$ には明らかに温度依存性があるこ とがわかったが, 温度上昇による $m_{0}$ の増加和よび $D_{0}$ の低下の傾向すなわら， $m_{1}^{*}$ ， $Q$ の值には，両銅材に お汀る差は核とえどない。

そこで， $m_{0}, D_{0}$ の温度依存性の式(5)，(6)を式(4)に 代入することにより，任意の高温 $T_{\theta}(K)$ 条件下での 衝撃疲労強度特性は，一般に次式で表されることにな る. 

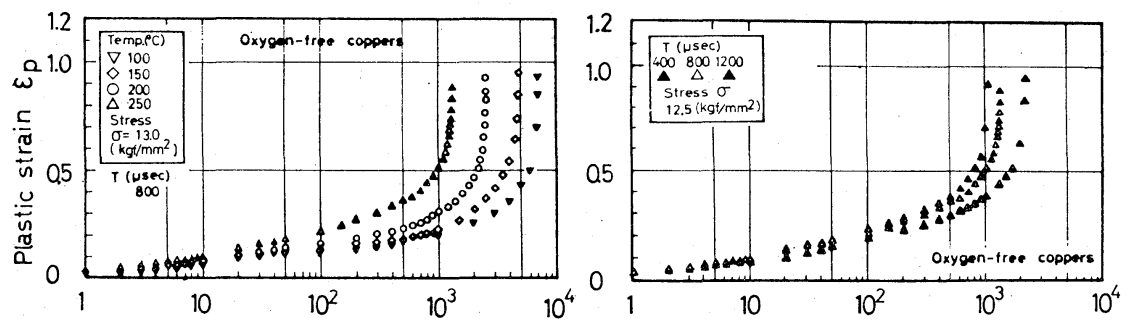

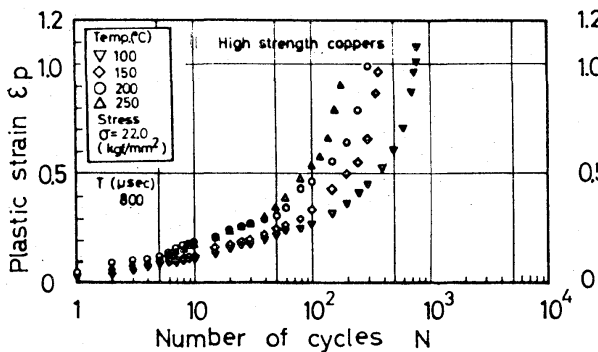

(a)

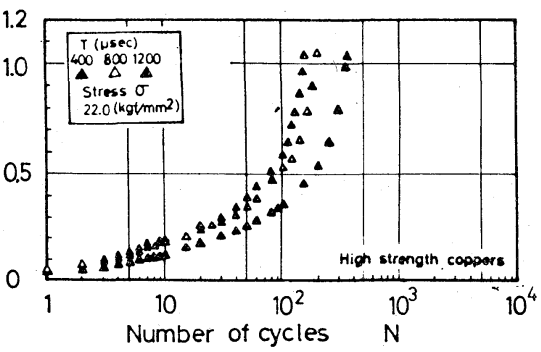

(b)

Fig. 6. Influence of stress-magnitude $\sigma$ or cumulative duration time $\left(N_{f} T\right)$ on the behaviors of cyclic creep deformation in the impact fatigue process under high temperatures.

$\sigma\left(N_{f} T\right)^{m} 0^{*+m_{1} *\left(T_{\theta}-273\right)}=D_{0} * \exp \left(Q / k T_{\theta}\right)$

$3 \cdot 2$ 高温衝撃疲労過程でのサイクリッククリープ による塑性変形挙動特性

Fig. 6 (a)(b)は高温条件下で軟質無酸素銅および高力 銅が衝撃引張応力を繰返し受けて疲労破壞する過程で のサイクリッククリープによる塑性変形挙動について, それぞれ，代表例を示したものである. Fig. 6 (a)は負 荷持続時間 $T=800 \mu \mathrm{sec}$ の衝撃負荷応力 $\sigma$ 一定で 100 , $150,200,250^{\circ} \mathrm{C}$ 各温度条件下での塑性ひずみ $\varepsilon_{p}$ と 衝撃負荷の繰返し数 $N$ との関係を示したものである. 一方, Fig. 6 (b)は同一温度条件下で負荷持続時間 $T$ の 異なる一定衝撃負荷応力を繰返し受けた場合の塑性ひ ずみ $\varepsilon_{p}$ と衝撃負荷の繰返し数 $N$ との関係を示したも のである.これらの $\varepsilon_{p}-N$ 曲線からわかるように, 同 一温度条件下でのサイクリッククリープによる塑性変 形速度 $\Delta \varepsilon / \Delta N$ は衝撃負荷応力 $\sigma$ の大ささのみならず, その負荷持続時間 $T$ に明らかに依存し， $T$ が長くなる ほど，速くなる傾向がある。

Fig. 7 (a)(b)は衝撃負荷の繰返し数 $N$ を破壊寿命 $N_{f}$ で正規化し，サイクリッククリープによる塑性ひずみ $\varepsilon_{p}$ を $\left(N / N_{f}\right)$ との関係で表したものである.これら の $\varepsilon_{p}-\left(N / N_{f}\right)$ 曲線からわかるように衝撃疲労過程で のサイクリッククリープによる塑性ひずみ $\varepsilon_{p}$ の挙動 は，いずれの温度条件あるいは負荷条件においてもi） 初期クリープ領域, ii) 最小クリープ速度領域, iii) 加速クリープ領域，の領域に明りょらに区分できる. いずれの銅材も, 最小クリープ速度領域が全衝撃疲労 過程の約 $90 \%$ を占め， 3〜 $5 \%$ を占める初期クリープ 領域あるいは $5 \sim 7 \%$ 占める加速クリープ領域に比
ベて極めて長い.したがって，高温の場合も，前報の 室温の場合と同樣, 最小クリープ速度領域の寿命が衝 撃疲労過程, すなわち, 衝撃疲労寿命 $N_{f}$ を完全に支 配すると考光てよい. 各クリープ領域での塑性ひずみ 増分 $\Delta \varepsilon_{p}{ }^{\mathrm{I}}, \Delta \varepsilon_{p}$ II, $\Delta \varepsilon_{p}$ III に注目してみた場合, Table IV に示すように両銅材に揖いて明りょうな差異が認 められる. $\Delta \varepsilon_{p}$ II が $48 \sim 53 \%$ の軟質無酸素銅に比べて, 高力銅の $\Delta \varepsilon_{p}$ II は32 $37 \%$ と減少している.これは, 軟質無酸素銅の場合, 加速クリープ領域に入って大き な局部収縮を起し平均的な軸方向伸びも大きくなるの に対して, 高力銅の場合, 加速クリープ領域に入って の局部収縮は比較的小さく平均的な軸方向伸びがそれ ほど加速されないのに起因している.

Fig. 8 は衝撃疲労破壊後の破断伸びひずみ $\varepsilon_{f}$ で $\varepsilon_{p}$ を除して正規化し， $\left(\varepsilon_{p} / \varepsilon_{f}\right)$ と $\left(N / N_{f}\right)$ との関係を 示したものである. このよらに各サイクリッククリー プ領域での塑性ひずみ增分 $\Delta \varepsilon_{p} \mathrm{I}, \Delta \varepsilon_{p} \mathrm{II}, \Delta \varepsilon_{p} \mathrm{III}$ を, $\varepsilon_{f}$ に対する比率で着目してみると，いずれの銅材に拈い ても, $\Delta \varepsilon_{p}$ II は $\varepsilon_{f}$ の52 60\%であり, $\Delta \varepsilon_{p}^{\mathrm{I}}$ との累積 で $\varepsilon_{f}$ の63〜 76\%に達すると加速クリープ領域に入り, $\varepsilon_{f}$ の $24 \sim 32 \%$ 塑性変形が急速に進行して破断に至 る.

Fig. 9 は，常温と高温での衝撃疲労過程に打けるサ イクリッククリープによる塑性ひずみ $\varepsilon_{p}$ の挙動を, 同一図上に $\left(N / N_{f}\right)$ との関係で示している. いずれ の銅材においても，常温と高温 $\left(100 \sim 250^{\circ} \mathrm{C}\right)$ の場合 での差異はほとんど無視できる程度のものである. し たがって，高温の場合も，前報で明らかにした常温で の場合同様に $N / N_{f}=x_{N}$ をパラメータとして衝撃疲 

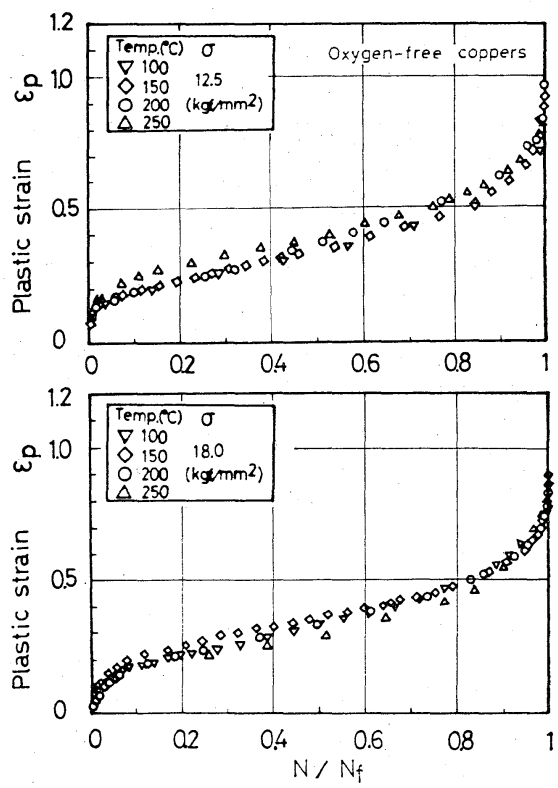

(a)
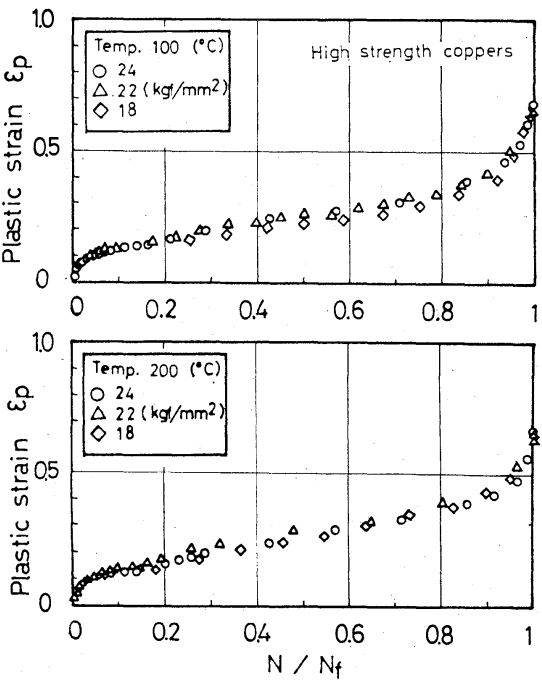

(b)

Fig. 7. Relations between plastic strain $\varepsilon_{p}$ and normalized number of cycles $N / N_{f}$ at high temperatures.

Table IV. Increments of plastic strain within each cyclic creep region in the impact fatigue process.

\begin{tabular}{|c|c|c|c|c|}
\hline & $\begin{array}{l}\text { Primary } \\
\text { creep } \\
\text { region }\end{array}$ & $\begin{array}{l}\text { Minimum } \\
\text { creep rate } \\
\text { region }\end{array}$ & $\begin{array}{l}\text { Accelative } \\
\text { creep } \\
\text { region }\end{array}$ \\
\hline Oxygen-free & $\Delta \varepsilon_{p}$ & $9 \sim 17 \%$ & $48 \sim 53 \%$ & $23 \sim 30 \%$ \\
\hline coppers & $\Delta \varepsilon_{p} / \varepsilon_{f}$ & $10 \sim 19 \%$ & $53 \sim 59 \%$ & $25 \sim 33 \%$ \\
\hline High-strength & $\Delta \varepsilon_{p}$ & $7 \sim 10 \%$ & $32 \sim 37 \%$ & $15 \sim 20 \%$ \\
\hline coppers & $\Delta \varepsilon_{p} / \varepsilon_{f}$ & $11 \sim 16 \%$ & $52 \sim 60 \%$ & $24 \sim 32 \%$ \\
\hline
\end{tabular}
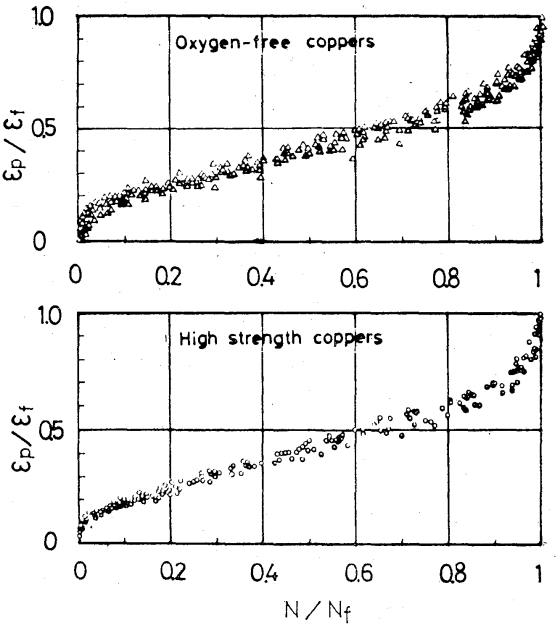

Fig. 8. Relation between normalized plastic strain $\varepsilon_{p} / \varepsilon_{f}$ and normalized number of cycles $N / N_{f}$ at high temperatures.
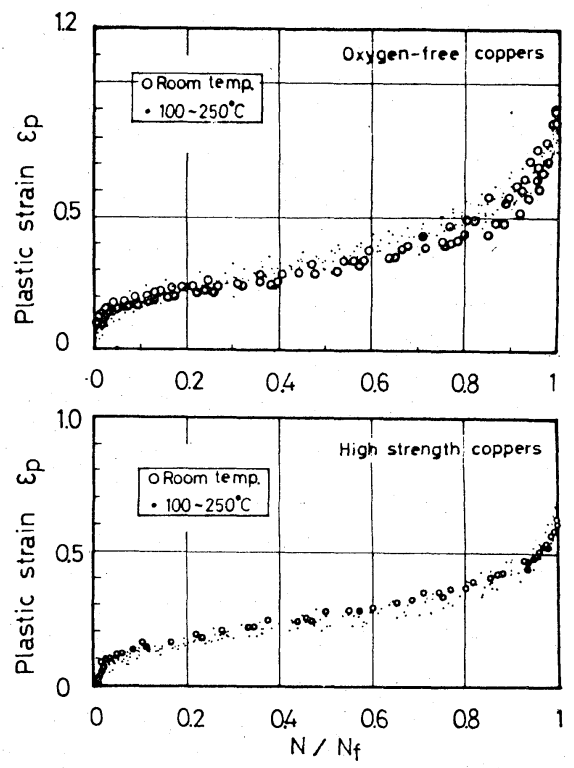

Fig. 9. Relation between plastic strain $\varepsilon_{p}$ and normalized number of cycles $N / N_{f}$ at room and high temperatures.

労過程での $\varepsilon_{p}$ の挙動を次式で表すことができる.

$$
\begin{aligned}
\varepsilon_{p}= & \left(a_{1} x_{N}+a_{2}\right)\left\{1-\exp \left(-x_{N} / a_{3}\right)\right\} \\
& +a_{4} \exp \left\{\left(x_{N}-1\right) / a_{5}\right\}
\end{aligned}
$$

ここで， $a_{1} \sim a_{5}$ は材料定数で，これらの值を Table $\mathrm{V}$ に示す. この式(8)に捈いて $a_{1} x_{N}+a_{2}$ は最小クリー プ速度領域での塑性ひずみ $\varepsilon_{p}$ I の挙動を表 し，第 1 項の $\left(a_{1} x_{N}+a_{2}\right)\left\{1-\exp \left(-x_{N} / a_{3}\right)\right\}$ は初期クリープ 領域から最小クリープ速度領域にわたっての $\varepsilon_{p}$ の挙 動を表す. 第 2 項の $a_{4} \exp \left\{\left(x_{N}-1\right) / a_{5}\right\}$ は加速クリ ープ領域での $\varepsilon_{p}$ の増分 $\Delta \varepsilon_{p}$ II のみを表している.

一方, 破壊寿命 $N_{f}$ は式(7)より衝撃負荷応力の大 
Table V. Material constants in the formula for the behaviors of plastic strain.

\begin{tabular}{c|c|c|c|c}
\hline$a_{1}$ & $a_{2}$ & $a_{3}$ & $a_{4}$ & $a_{5}$ \\
\hline 0.32 & 0.15 & 0.021 & 1.20 & 0.031 \\
\hline
\end{tabular}

きさ $\sigma$, その負荷持続時間 $T$ 特よび温度 $T_{\theta}(\mathrm{K})$ の関 数として次式のように表されるので， $x_{N}\left(=N / N_{f}\right)$

$$
\begin{aligned}
N_{f} & =\frac{1}{T}\left(D_{0} / \sigma\right)^{1 / m_{0}} \\
& =\frac{1}{T}\left\{\frac{D_{0} *}{\sigma} \exp \left(Q / k T_{\theta}\right)\right\}^{1 /\left\{m_{0} *+m_{1} *\left(T_{\theta}-273\right)\right\}}
\end{aligned}
$$

は次式のように与えられる.

$$
x_{N}=(N T)\left\{\frac{\sigma}{D_{0}^{*}} \exp \left(-Q / k T_{\theta}\right)\right\}^{1 /\left\{m 0^{*+m_{1}} 1^{\left.*\left(T_{\theta}-273\right)\right\}}\right.}
$$

したがって，任意の高温条件下での衝撃疲労過程に おけるサイクリッククリープによる塑性ひずみ $\varepsilon_{p}$ の 挙動は式(10)を式(8)に代入乙衝撃負荷の繰返し数 $N$ を増 しながら計算して行くことにより推定でさる.

また，最小クリープ速度領域での $\varepsilon_{p}$ の挙動は式(8) に蛙ける $a_{1} x_{N}+a_{2}$ の項の㕛で表されるので, 衝撃疲 労寿命 $N_{f}$ の約 $90 \%$ を支配するところの最小クリープ 速度領域での $\varepsilon_{p}$ I としては，次式で表される.

$\varepsilon_{p} \mathrm{II}=a_{1}(N T)\left\{\frac{\sigma}{D_{0} *} \exp \left(-Q / k T_{\theta}\right)\right\}^{1 /\left\{m_{0} *+m_{1} *\left(T_{\theta}-273\right)\right\}}$

\section{$3 \cdot 3$ 高温衝撃疲労強度とその疲労過程における塑} 性変形挙動の静的引張特性值に基づく推定

衝撃疲労強度特性パラメータ $\left(m_{0}, D_{0}\right)$ は, 常温に 扣いては, 静的引張特性值 (引張強さ $\sigma_{B}$, 破断絞り $\varphi ）$ と次式のような関係があることを明らかにし，そ れに対する考察を前報で論じている.

$$
\begin{gathered}
D_{0}=(0.77+0.0019 \varphi) \sigma_{B} \\
m_{0}=1.357 \times 10^{-3}(\varphi-26.32)
\end{gathered}
$$

本報では，高温条件下での場合について検討してい くことにする.

Fig. 5 にみられるよらに温度上昇による $m_{0}$ の増大 の傾向および $D_{0}$ の低下の傾向は，温度に依存せず一

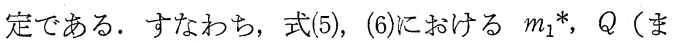
たは $\left.Q^{*}\right)$ は一定である.乙かも，両銅材に抢けるこ れらの值の差はほとんど無視できる程度のものである ので, 両銅材の $m_{1} *, Q$ の平均值を $\hat{m}_{1}^{*}, \hat{Q}$ とし, 各銅材の常温 $\left(T_{\theta S}\right)$ での静的引張特性值を $\left(\sigma_{B S}, \varphi_{S}\right)$ とすると, 任意の高温 $T_{\theta}(\mathrm{K})$ 条件下での衝撃疲労強 度特性パラメータ $m_{0}\left(T_{\theta}\right), D_{0}\left(T_{\theta}\right)$ は，それぞれ， 式(12)，(13)より次式のように表される.

$$
m_{0}\left(T_{\theta}\right)=1.357 \times 10^{-3}\left(\varphi_{S}-26.32\right)+\hat{m}_{1} *\left(T_{\theta}-T_{\theta S}\right)
$$

$D_{0}\left(T_{\theta}\right)=\left(0.77+0.0019 \varphi_{S}\right) \sigma_{B S} \exp \left\{\frac{\hat{Q}}{k}\left(\frac{1}{T_{\theta}}-\frac{1}{T_{\theta S}}\right)\right\}$

したがって，常温〜高温 $\left(250^{\circ} \mathrm{C}\right)$ の範囲内での任 意温度条件下での繰返し衝撃引張荷重に対する疲労強

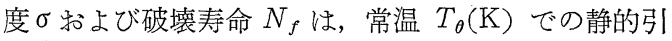
張特性值 $\left(\sigma_{B S}, \varphi_{S}\right)$ を基に，それぞれ，次式で推定 できる。

$$
\begin{aligned}
\sigma= & (0.77+0.0019 \varphi) \sigma_{B S} \exp \left[\frac{\hat{Q}}{k}\left(\frac{1}{T_{\theta}}-\frac{1}{T_{\theta S}}\right)\right. \\
& -\left\{1.375 \times 10^{-3}\left(\varphi_{S}-26.32\right)\right. \\
& \left.\left.+\hat{m}_{1} *\left(T_{\theta}-T_{\theta S}\right)\right\} \ln \left(N_{f} T\right)\right] \\
N_{f}= & \frac{1}{T} \exp \\
& \left\{\frac{\ln \left(0.77+0.0019 \varphi_{S}\right) \sigma_{B S}-\ln \sigma+\frac{\hat{Q}}{k}\left(\frac{1}{T_{\theta}}-\frac{1}{T_{\theta S}}\right)}{1.375 \times 10^{-3}(\varphi-26.32)+\hat{m}_{1} *\left(T_{\theta}-T_{\theta S}\right)}\right]
\end{aligned}
$$

また，この衝撃疲労過程でのサイクリッククリープ による塑性ひずみ $\varepsilon_{p}$ の挙動の推定におけるパラメー タ $x_{N}\left(=N / N_{f}\right)$ としては, 次式で与えられる.

$$
\begin{aligned}
x_{N} & =\frac{N}{N_{f}}=(N T) \exp \\
& \left\{\frac{1.375 \times 10^{-3}(\varphi-26.32)+\hat{m}_{1}^{*}\left(T_{\theta}-T_{\theta S}\right)}{\ln \left(0.77+0.0019 \varphi_{S}\right) \sigma_{B S}-\ln \sigma+\frac{\hat{Q}}{k}\left(\frac{1}{T_{\theta}}-\frac{1}{T_{\theta S}}\right)}\right\}
\end{aligned}
$$

一方，Fig. 9 にみられるように(1)高温と常温とに拉 いて $\varepsilon_{p}-\left(N / N_{f}\right)$ 関係が汪注一致すること. しかも， Fig. 8 にみられるように(2) $\left(\varepsilon_{p} / \varepsilon_{f}\right)-\left(N / N_{f}\right)$ 関係で は軟質無酸素銅と高力銅とに差がなく一致すること. および(3)衝撃疲労過程の $90 \%$ を占める最小クリープ速 度領域での塑性ひずみ増分 $\Delta \varepsilon_{p}$ II が破断伸びひずみ $\varepsilon_{\delta}$ の45\%の量に相当し，乙かも，累積塑性ひずみ $\varepsilon_{p}$ が $\varepsilon_{\delta}$ の $70 \%$ に達すると加速クリープ 領域に入ること, などに着目して $\varepsilon_{p}$ の挙動と静的破断伸び $\delta(\%)$ とを

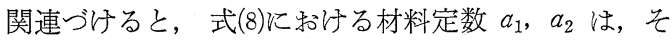
れぞれ，次式のようになる．他の材料定数

$$
a_{1}=0.005 \delta, a_{2}=0.00225 \delta
$$

$a_{3}, a_{4}, a_{5}$ は，各銅材の $\delta$ の值に依存せず，一定の值 と考えてよく，いずれの銅材に対しても，それぞれ同 一值を用いてよい。

したがって，任意の高温条件下での衝撃疲労過程に 括けるサイクリッククリープによる塑性変形挙動も, 式(18)の $\varepsilon_{N}$ を次式に代入して衝撃負荷の繰返し数 $N$ を 増しながら破壊寿命 $N_{f}$ の回数まで計算していくこと により, 常温での静的引張特性值 $\left(\sigma_{B S}, \varphi_{S}, \delta_{S}\right)$ か ら十分推定評価できることになる.

$$
\varepsilon_{p}=\left(0.005 x_{N}+0.00225\right) \delta_{S}\left\{1-\exp \left(-x_{N} / a_{3}\right)\right\}
$$




$$
+a_{4} \exp \left\{\left(x_{N}-1\right) / a_{5}\right\}
$$

以上のように, 各銅材の衝撃疲労強度特性パラメー タおよびそれらの温度依存性を, 各銅材の静的引張特 性值 $\left(\sigma_{B}, \varphi, \delta\right)$ と関連つ汓て, 高温衝撃疲労強度拉 よびその疲労過程での塑性変形挙動を推定評価できる ようになったことは，前報での常温の場合同様に，任 意の高温条件下での場合に，軟・硬質タフピッチ銅や 硬質無酸素銅などの他の銅材に対して衝撃疲労強度や 破壊寿命あるいはとの㾉労過程での塑性変形挙動を推 定評価して行く上に非常に有効である.

$$
4 \text { ま と め }
$$

軟質無酸素銅および高力銅に対して $100 \sim 250^{\circ} \mathrm{C}$ の温 度範囲の高温条件下での繰返し衝撃引張荷重に対する 衝撃疲労強度およびその疲労過程でのサイクリックク リープによる塑性変形挙動の温度依存性を実験的に究 明した。 ついで，これらの特性を表すパラメータと静 的引張特性值との関連性について解析し, 常温での静 的引張特性值に基つく高温衝撃疲労強度およびその疲 労過程での塑性変形挙動の推定評価を検討した.

（1）両銅材の高温衝撃引張疲労強度は, 常温での場 合同様，次式で表すことができ，衝撃疲労強度特性

$$
\sigma\left(N_{f} T\right)^{m_{0}}=D_{0}
$$

パラメータ $\left(m_{0}, D_{0}\right)$ に温度依存性を次式のように表

$$
\begin{aligned}
& m_{0}=m_{0} *+m_{1} *\left(T_{\theta}-273\right) \\
& D_{0}=D_{0} * \exp \left(Q / k T_{\theta}\right)
\end{aligned}
$$

せる、したがって，任意の高温 $T_{\theta}(K)$ 条件に対して は次式で表される。

$$
\begin{aligned}
& \sigma\left(N_{f} T\right)^{m} 0^{*+m_{1}} 1^{*\left(T_{\theta}-273\right)}=D_{0} \exp \left(Q / k T_{\theta}\right) \\
& \text { ここで, } m_{0} *, m_{1} *, Q \text { : 材料定数 }
\end{aligned}
$$

(2) 高温衝撃疲労過程でのサイクリッククリープル よる塑性ひずみ $\varepsilon_{p}$ の挙動としては, 高温条件下での 衝撃疲労破壞寿命 $N_{f}$ に対して衝撃負荷の繰返し数 $N$ の比 $N / N_{f}=x_{N}$ を次式のように求め， $x_{N}$ をパラメー タ

$$
x_{N}=(N T)\left\{\frac{\sigma}{D_{0} *} \exp \left(-Q / k T_{\theta}\right)\right\}^{1 /\left\{m_{0} *+m_{1} *\left(T_{\theta}-273\right)\right\}}
$$

として，常温での場合同様，次式で推定できる.

$$
\begin{aligned}
\varepsilon_{p}= & \left(a_{1} x_{N}+a_{2}\right)\left\{1-\exp \left(-x_{N} / a_{3}\right)\right\} \\
& +a_{4} \exp \left\{\left(x_{N}-1\right) / a_{5}\right\}
\end{aligned}
$$

ここで, $a_{1} \sim a_{5}:$ 材料定数

（3）任意の高温 $T_{\theta}(\mathrm{K})$ での衝撃疲労強度特性パラ メ一タ $m_{0}\left(T_{\theta}\right), D_{0}\left(T_{0}\right)$ は, 常温 $T_{\theta S}(K)$ での静的 引張特性值 (引張強さ $: \sigma_{B \varphi}$, 絞り $: \varphi_{S}$ ) から次式の ように推定でき，

$$
\begin{aligned}
& m_{0}=1.375 \times 10^{-3}\left(\varphi_{S}-26.32\right)+\hat{m}_{1} *\left(T_{\theta}-T_{\theta S}\right), \\
& D_{0}=\left(0.77+0.0019 \varphi_{S}\right) \sigma_{B S} \exp \left\{\frac{\hat{Q}}{k}\left\{\left(\frac{1}{T_{\theta}}-\frac{1}{T_{\theta S}}\right)\right\}\right.
\end{aligned}
$$

衝撃疲労破壊寿命 $N_{f}$ を支配するところの最小クリ一 プ速度領域での塑性ひずみの挙動を表す $\varepsilon_{p}=\Delta \varepsilon_{p}{ }^{\mathrm{I}}+$ $\varepsilon_{p}$ II $=a_{1} x_{N}+a_{2}$ での材料定数 $a_{1}, a_{2}$ は, それぞれ, 次 式のように常温での静的引張りによる破断伸び $\delta(\%)$ から推定できる。

$$
a_{1}=0.005 \delta, \quad a_{2}=0.00225 \delta
$$

したがって，本実験での軟質無酸素銅や高力銅のみ ならず，他の純銅材，例えばタフピッチ銅や硬質無酸 素銅などに対しても，高温衝撃疲労強度やその疲労過 程での塑性変形挙動を, 各銅材の常温での静的引張特 性值に基づき推定評価でき，衝撃疲労強度設計上での 簡便な評価手法として工学的に非常に役に立つ. （昭和56年10月 6 日 第 25 回材料研究連合講演会にて講演）

\section{参 考 文 献}

1) 岡部永年, 有井 満, 森 忠夫, 内田 猛, 矢野利行, 第17回材料研究連合講演会前刷集, p. 141 (1973).

2) 岡部永年, 矢野利行, 森 忠夫, 材料, 33, 1186(1984).

3) S.S. Manson, NACA Rep., 1170 (1954).

4) L.F. Coffin, Trans. ASME, 76, 931 (1954).

5）鵜戸口英善, 朝田泰英, 材料, 14, 152 (1965).

6) S.S. Manson, Exp. Mech., 5, 193 (1965).

7) S.S. Manson, G. R. Halford and D.A. Spera, The Role of Creep in High Temperature Low Cycle Fatigue, A. E. Johnson Memorial Volum (1969).

8) D.A. Spera, NASA-TMX-52558 (1969).

9) M. A. Miner, J. Appl. Mech., 12, 1 (1945).

10) E. L. Robinson, Trans. ASME, 74, 777 (1952).

11) E. Krempl and C.D. Walker, ASTM STP 459, 75 (1968).

12) C. H. Wells and C.P. Sullivan, ASTM STP 459, 59 (1968). 